\title{
A Series on Diseases in the Florida Vegetable Garden: Watermelon 1
}

\section{Pamela Roberts, Rosa Muchovej, Tom Kuch Florida Vegetable Garden}

Many Floridians delight in maintaining a vegetable garden in their backyard. Others keep several pots of popular vegetables on patios or similar residential sites. Our long growing season and generally mild climate are ideal for the gardening enthusiast. Furthermore, the health benefits of moderate gardening activity are well documented, and the supply of wholesome garden-fresh vegetables and fruits adds to our quality of life in the Sunshine State.

Sometimes pest problems interfere with our gardening pursuits. Some problems, such as weeds and certain insects, are relatively easy to identify as causing damage. However, another group of maladies, plant diseases, can cause serious damage and are underappreciated and not as well understood by many homeowners.

The majority of plant health problems categorized as plant diseases are caused by 
again and attack plant roots, causing disease. The majority of diseases you are likely to find in your home garden are caused by fungi.

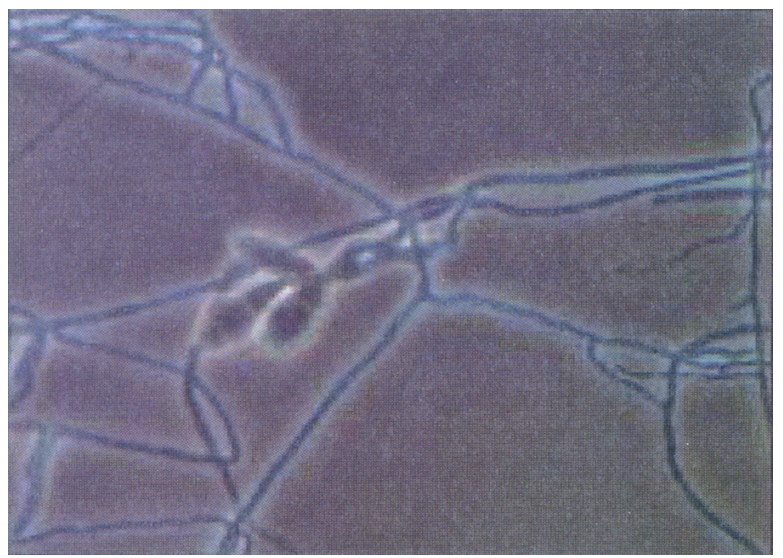

Figure 1. Microscopic threads (hyphae) and spores of a typical plant-pathogenic fungus.

\section{Bacteria}

Bacteria are even smaller than fungi (you need a 1000x magnification with a special light microscope to see them) (Fig. 2). They consist of only one cell and do not form the airborne spores that fungi do. Rather than being blown by the wind, bacteria are usually spread by splashing water, as in rainstorms or overhead sprinkler irrigation. They can also be spread by gardeners who touch diseased plants and healthy plants in succession without thoroughly washing their hands in-between.

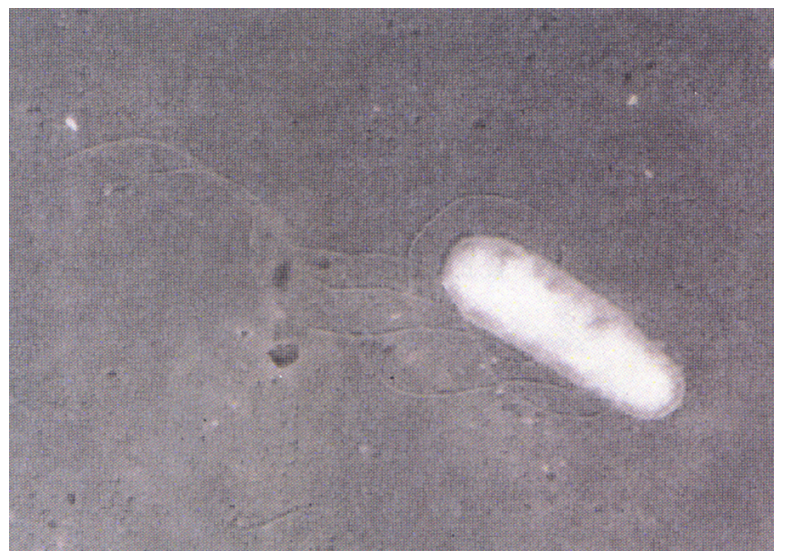

Figure 2. A bacterial cell. Credits: Photo courtesy of Scott Adkins, USDA

\section{Viruses}

Viruses are most strange indeed (Fig. 3). They are not "organisms" in the sense of the fungi and bacteria. They are very large molecular structures consisting of a nucleic acid (DNA or RNA) wrapped in a protective coating of protein. Once inside watermelon cells, they take over the host cellular machinery and use it to produce more viruses. Most of the important viruses are transmitted to garden plants by insects such as aphids, whiteflies, or thrips.

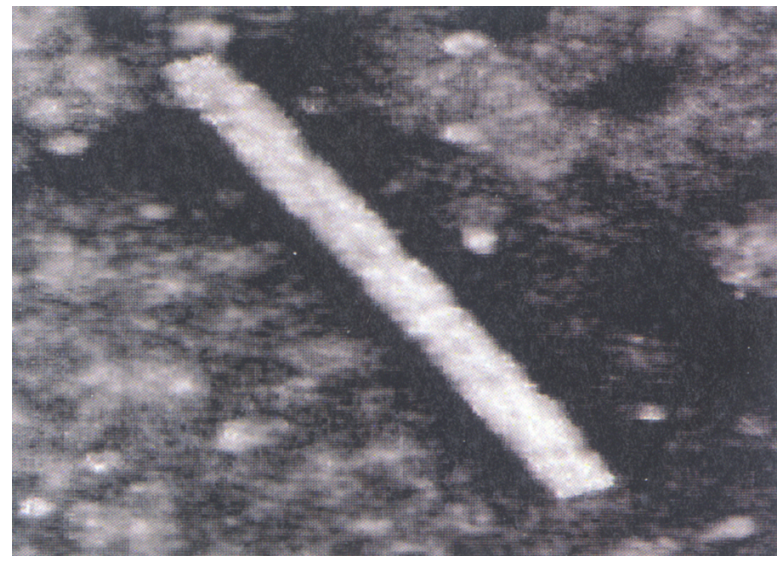

Figure 3. Typical rod shaped virus as seen through a powerful electron microscope. Credits: Photo courtesy of Scott Adkins, USDA

\section{Specific Common Watermelon Diseases}

The following diseases are a few of the ones, in our experience, that are most likely to appear on your garden watermelons. This is not by any means an exhaustive list of watermelon diseases, but the ones we feel occur most often in Florida home gardens. If you have a problem that you think might be a disease not covered in this publication, search the EDIS database or that of the Department of Plant Pathology web site of IFAS University of Florida for information on additional watermelons diseases. Legal uses and effectiveness of plant disease control chemicals change with time. You are strongly advised to consult you local UF IFAS Cooperative Extension office for current disease management recommendations.

An accurate diagnosis of any plant problem is a pre-requisite for solving the problem, which may or may not be related to a biotic cause. An accurate identification is necessary for proper treatment of the disorder. Legal uses and effectiveness of plant disease control chemicals change with time. You are strongly advised to consult you local UF IFAS Cooperative Extension office for current disease management recommendations. 


\section{Alternaria Leaf Spot}

The causal fungus infects the leaves only. Lesions are usually round to irregular, dark brown or black, and frequently occur with concentric rings. Lesions of Alternaria leaf spot can often be confused with young gummy stem blight leaf spots because of the zonate appearance. The pathogen overseasons on old diseased plant debris. Spores are readily dispersed by wind and rain. Spores can be found in association with seed. See Plant Pathology Fact Sheet PP-32. Consult with the UF IFAS Cooperative Extension Service for recommended fungicides.

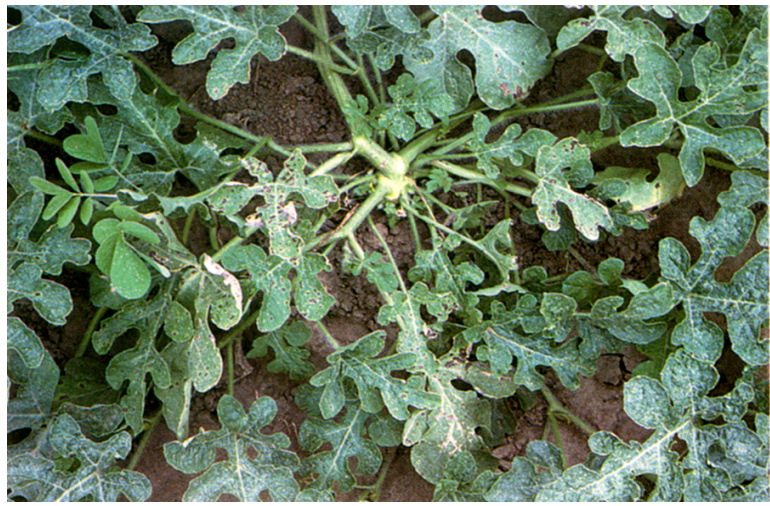

Figure 4. Alternaria leafspot on older watermelon leaves.

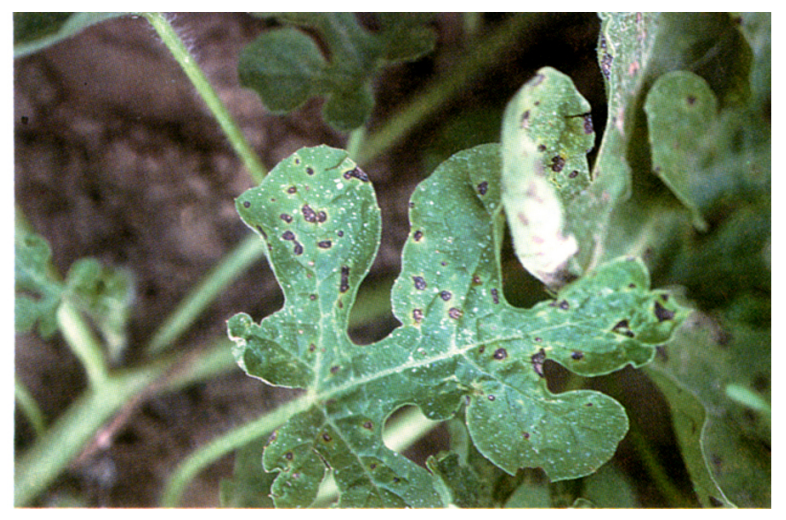

Figure 5. Variation of Alternaria leaf spot appearance on watermelon leaves.

\section{Anthracnose}

This fungus infects leaves, stems, and fruits. It is seedborne and the disease may first appear as a brown spot on seedling cotyledons. Leaf lesions are angular or irregular, dark brown to black, and usually with a narrow yellow border. Many lesions characteristically develop on a single leaf thus originating the term "measles" for this disease. Lesions on the stems are usually deep and elongate

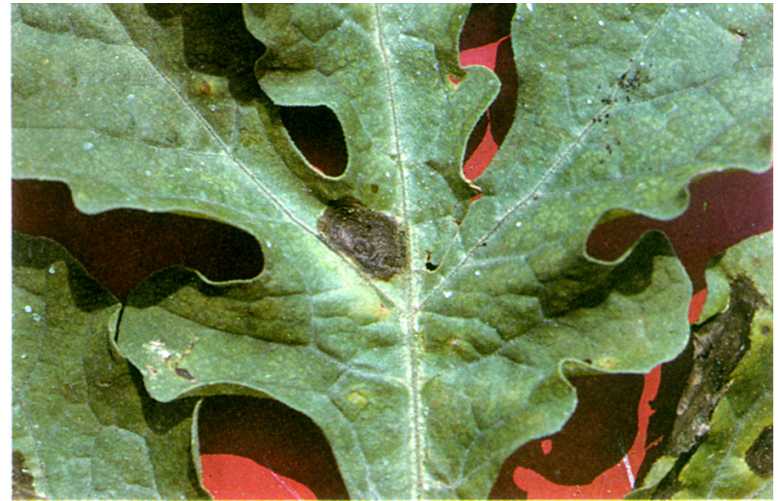

Figure 6. Zonate appearance of Alternaria leaf spot on watermelon leaf.

while those on the fruit are raised with sunken centers. The pathogen is spread from plant to plant in wind-driven rain and are carried by people and machinery moving through the vines when they are wet. Plant only anthracnose-resistant watermelon varieties. Bury plant residue and practice crop rotation. Prior to planting, choose a variety with resistance to this disease. Consult with the UF IFAS Cooperative Extension Service for recommended fungicides.

\section{Angular Leaf Spot}

The bacterium affects both leaves and fruit. On the leaves, lesions begin as small water-soaked circular black spots surrounded by a yellow halo. The center of the spots may become white. As they enlarge, lesions become angular in shape and may involve an entire lobe of even larger portions of the leaf. This is a cool, damp weather pathogen. The pathogen is seedborne and seedlings may exhibit watersoaked lesions on the cotyledon. On fruits, lesions begin as small circular water-soaked areas a few millimeters in diameter and enlarge with age to cover larger portions of the melon surface. Lesions do not penetrate deeply into the fruit. On large lesions the cuticle ruptures and peels free from the melon surface. Bacterial ooze may be present. The best control is to avoid the disease by buying and using disease-free seed. Prior to planting, choose a variety with resistance to this disease. Avoid working and touching the plants when they are wet. Consult with the UF IFAS Cooperative Extension Service for recommended copper fungicides. 


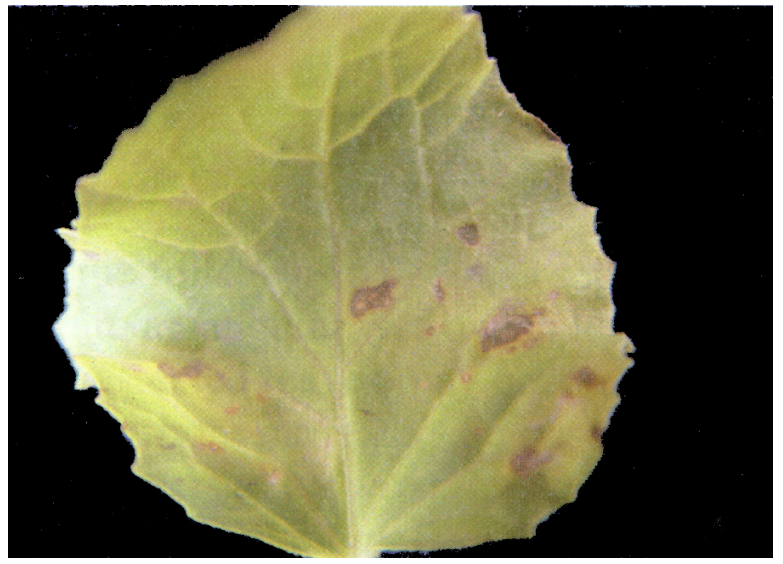

Figure 7. Angular leaf spot on young cantaloupe leaf.

\section{Bacterial Fruit Blotch}

Dark water-soaked lesions develop on the top or sides of watermelon fruit approximately 2 weeks before maturity or later. As these lesions expand, they crack and develop a brown, scaly appearance. Additional fruit breakdown occurs. The bacterium causes small, angular or linear necrotic lesions on true leaves. These lesions are small and similar to those caused by downy mildew or gummy stem blight. No significant leaf loss occurs. Lesions in seed leaves become necrotic, but they typically are water-soaked areas on the underneath side first. The pathogen is seedborne. Spread within a garden is by windsplashed rain, workers, or equipment. Wet conditions are favorable for disease development. As with the other bacterial diseases, use only pathogen-free, indexed seed and healthy transplants and avoid handling the plants when they are wet. Consult with the UF IFAS Cooperative Extension Service for recommended copper bactericides.

\section{Damping-Off}

Several soil-inhabiting fungi and fungal-like organisms that are almost universal in occurrence cause this disease affecting seedling watermelons. These fungi infect portions of the plant at or below the soil level, resulting in collapse and death of the seedling. Conditions unfavorable for rapid emergence of watermelons (cool, wet weather) are usually most favorable for this disease. See Plant Pathology Fact Sheet PP-1. Avoid planting seed when soil moisture, soil preparation, temperature or planting depth do not favor rapid emergence. Plant in well tilled soil where old crop debris had been destroyed 30 days previously.

\section{Downy Mildew}

This fungus primarily infects the leaves. Lesions first appear on the crown leaves as yellow, mottled spots with indefinite borders. Older lesions are dark brown, contrasting sharply with the healthy tissue, and with only a small yellow border. As several lesions coalesce, the leaf curls inward toward the midrib and presents a "cupped hand" appearance. Under favorable conditions, downy mildew develops rapidly, resulting in a "burned-off" appearance over the entire field. The pathogen is spread rapidly by means of airborne and rain-splashed spores. It is virtually impossible to avoid this disease in south Florida. See Plant Pathology Fact Sheet PP-2. Prior to planting, choose a variety with resistance to this disease. Consult with the UF IFAS Cooperative Extension Service for recommended fungicides.

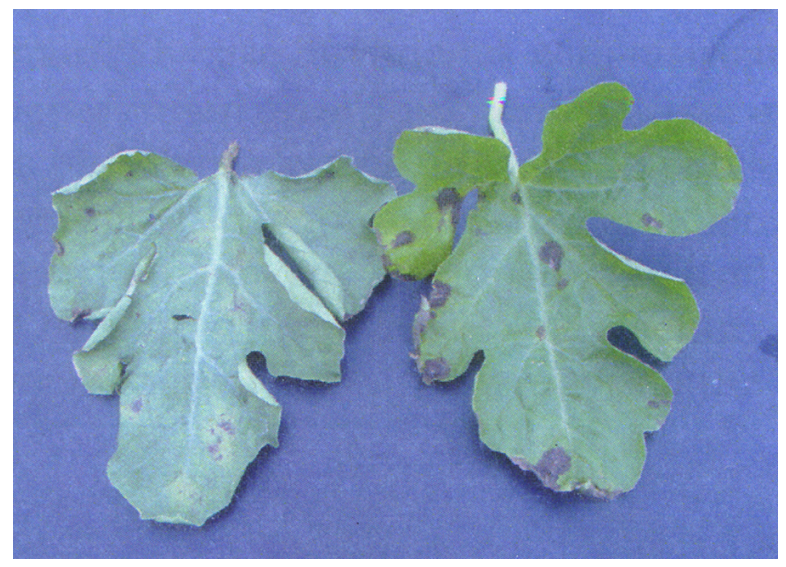

Figure 8. Downy mildew symptoms on left leaf and gummy stem blight symptoms on right leaf.

\section{Fusarium Wilt}

Infected plants develop a progressively severe wilt syndrome. Once the fungus is inside the plant, the water-conducting (vascular) system is colonized and becomes plugged, accounting for the wilt symptoms. Sectoring of wilt symptoms on one or more runners can occur. The vascular tissue in the crown develops a light brown to red discoloration. In severe cases, the entire root may become dark brown and a soft rot develops near the crown. The wilt cannot be overcome by thoroughly watering the plants. The pathogen can be spread to new areas on seed or in soil transported by equipment, drainage water, and man. See Plant Pathology Circular 1025. It can be an extremely difficult disease to control since it can survive indefinitely in the soil. 
To confirm Fusarium wilt, make a vertical cut of the lower stem of suspect plants and examine the water-conducting tissue. This is a narrow column of solid-appearing tissue to the outside of the stem. If it is brown, it could very well indicate Fusarium wilt.

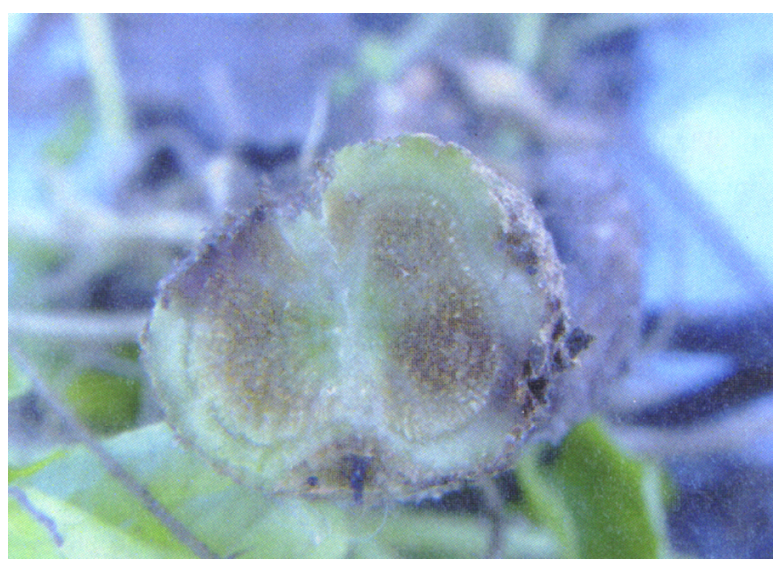

Figure 9. Internal browning of water-conducting tissue in watermelon stem of plant with Fusarium wilt.

Plant watermelon varieties with resistance to this disease. Control of Fusarium wilt for the home gardeners is primarily by use of varieties with resistance to the disease. Unfortunately, home gardeners often plant "old" varieties that are not resistant to this pathogen. If Fusarium is a problem in your garden, try to purchase resistant varieties that are sensible choices for the high disease pressure we can experience in Florida. Gardens planted on residential properties that were developed from land with a past history of watermelon farming, may be simply ill-suited for watermelons. Homeowners with this situation may have to bring in topsoil free of Fusarium and use a raised-bed system to be successful.

\section{Gummy Stem Blight}

This fungal pathogen can cause damping-off, crown rot, leaf spot, stem canker, and fruit rot of watermelon. Lesions in the cotyledons and leaves are round or irregular, brown and with faint concentric rings. Lesions on the crown and stem are brown and usually turn white with age. Lesions on fruit are brown, soft, nearly circular, and up to 4-6 inches in diameter. Lesions in stems and fruit may ooze or bleed an amber plant fluid: hence the name "gummy" stem blight. The pathogen is seedborne, spread by splashing rain from plant to plant, carried long distances on wind currents, and overseasons on old plant debris. See Plant Pathology Fact Sheet PP-27. To control this disease, use only disease-free seeds and transplants. Consult with the UF IFAS Cooperative Extension Service for recommended fungicides.

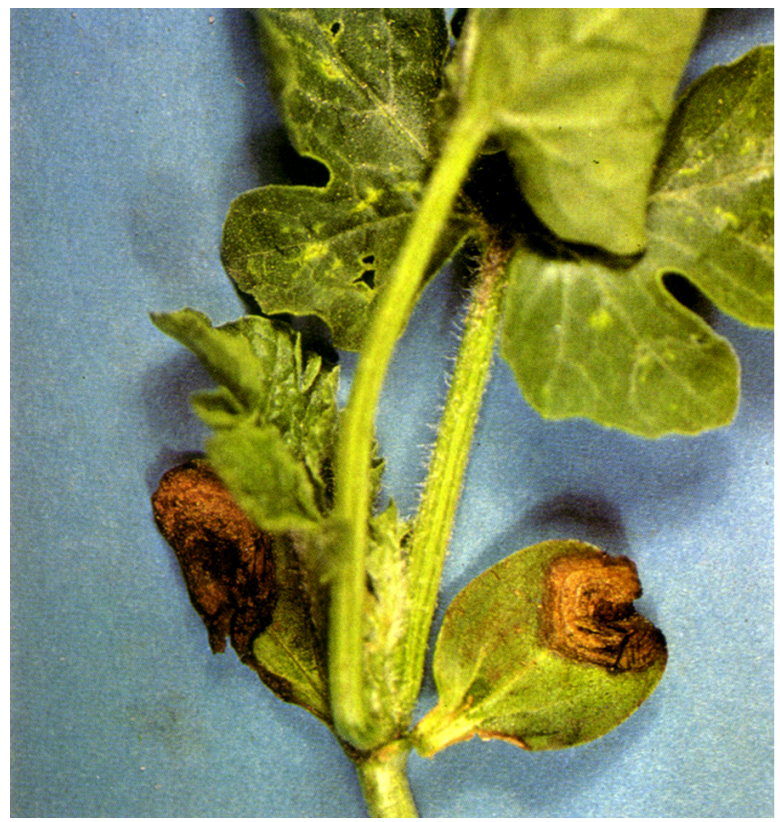

Figure 10. Gummy stem blight on watermelon seed leaves (cotyledons).

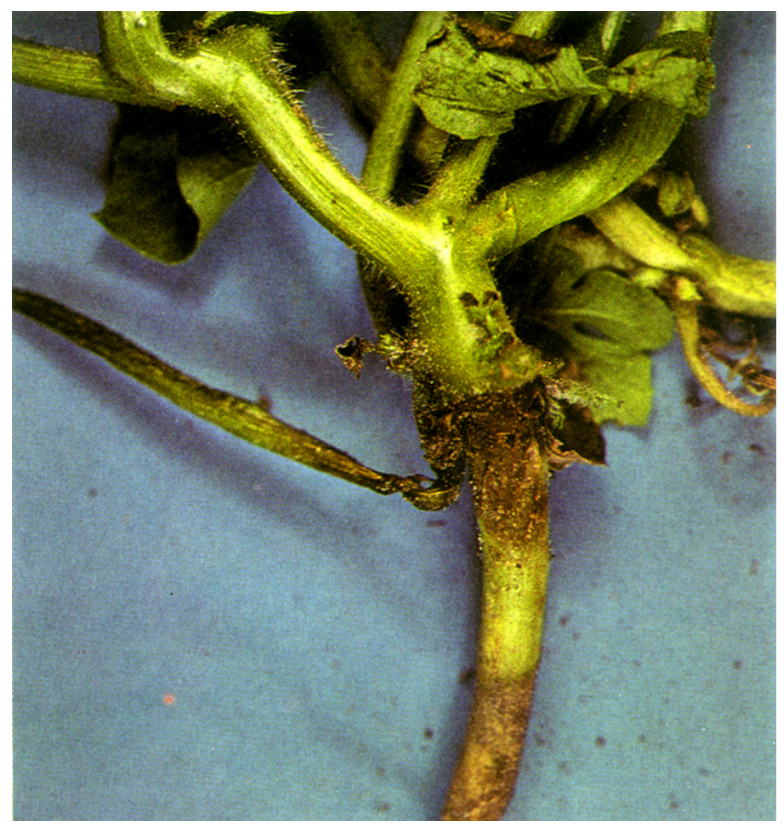

Figure 11. Early gummy stem blight on watermelon crown tissue. 


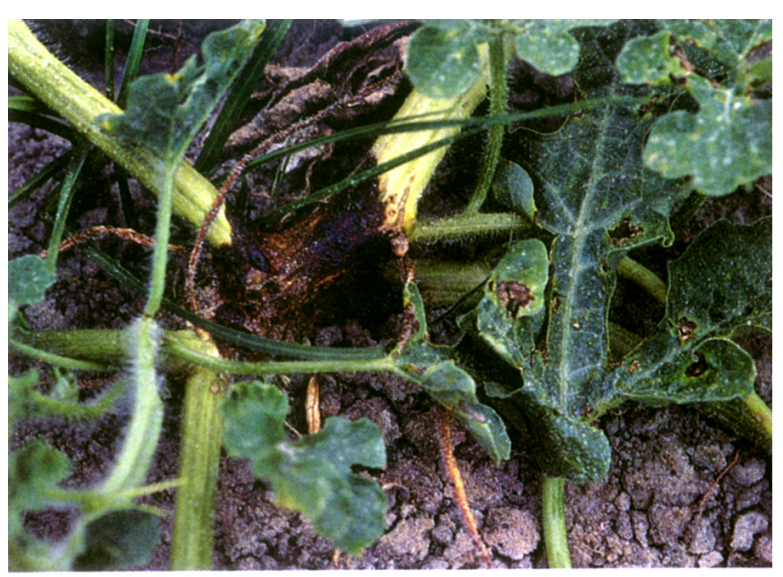

Figure 12. Late gummy stem blight on watermelon stem.

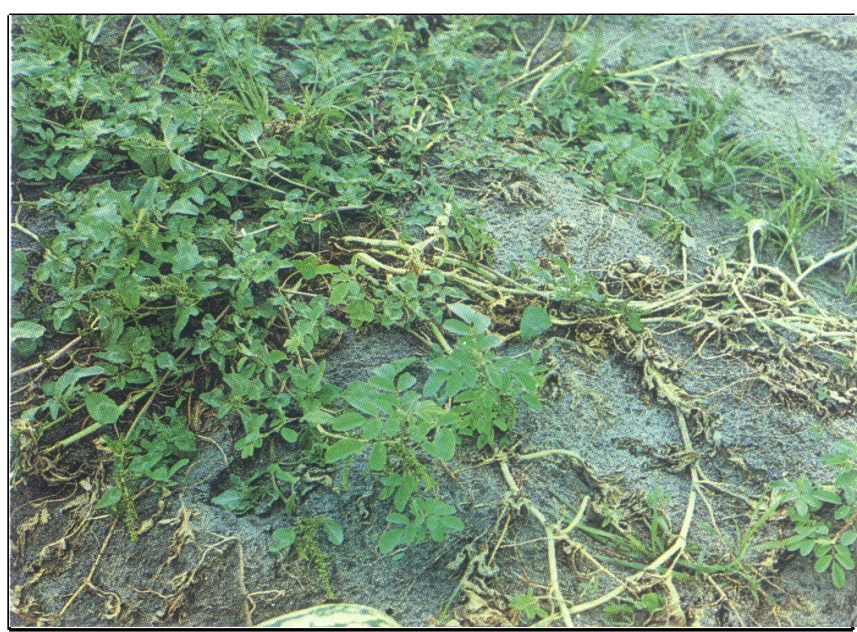

Figure 13. Watermelon vine wilting from gummy stem blight.

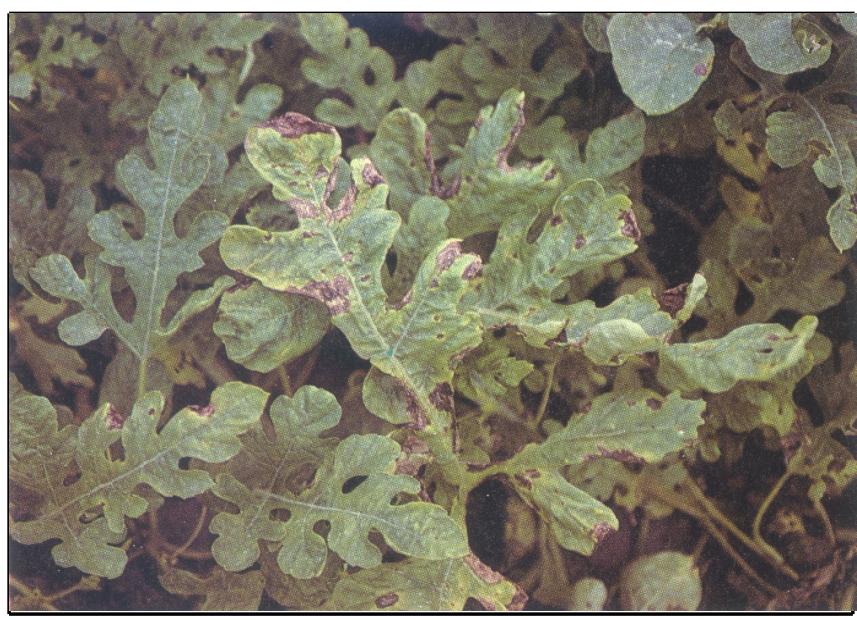

Figure 14. Gummy stem blight lesions on watermelon leaves.

\section{Phytophthora Blight and Fruit Rot (Phytophthora capsici)}

Any part of the plant can be infected by this fungus. However fruit symptoms are the most

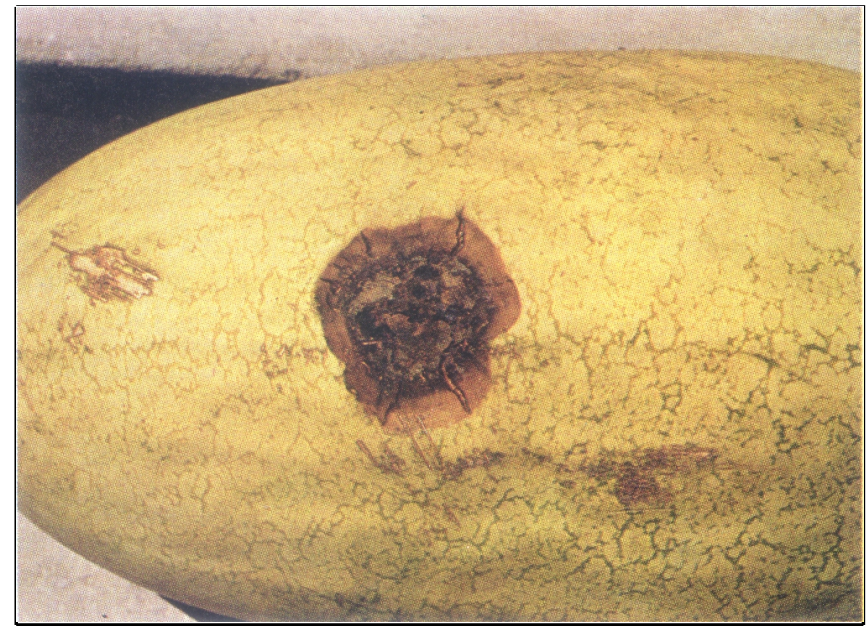

Figure 15. Gummy stem blight lesion on watermelon fruit.

commonly observed. When the roots of stems are infected, wilting of the plant will occur. A whitish mold may appear on the outside of the stem. The fruit rot will appear as greasy blotches on the outer rind. A whitish, mold is likely to be present on the greasy tissue. This disease is most likely to occur during or after periods of excessive rains where water stands for a period of time in the garden. To control this disease, avoid garden areas known to have had this disease, because the fungus can survive for many years in the soil. Provide for adequate drainage of water. Consult with the UF IFAS Cooperative Extension Service for recommended fungicides.

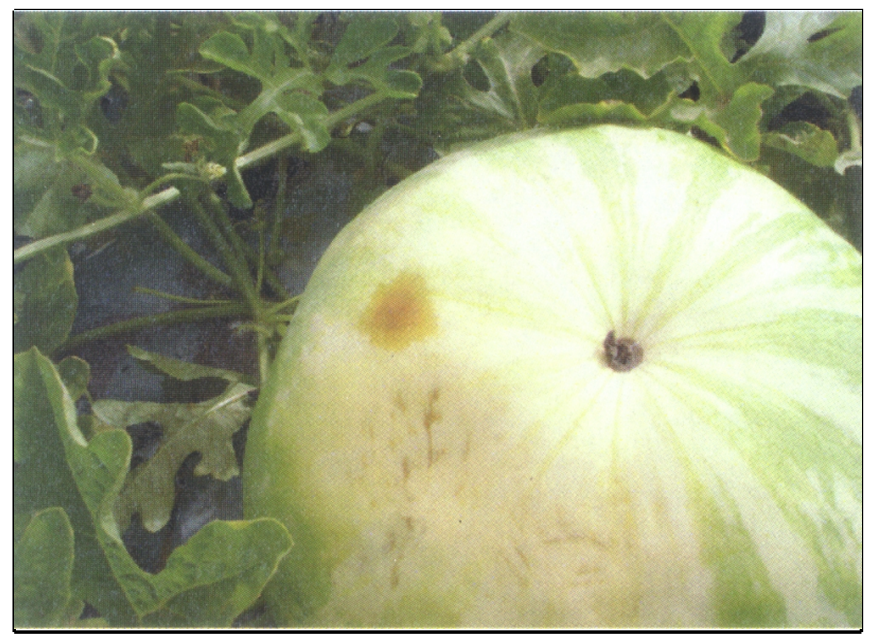

Figure 16. Watermelon fruit with beginning symptoms of Phytophthora blight.

\section{Powdery Mildew}

Initially, older leaves have a reddish-brown bronzed appearance. The reader must realize that viral infections, chemical phytotoxicity and certain 


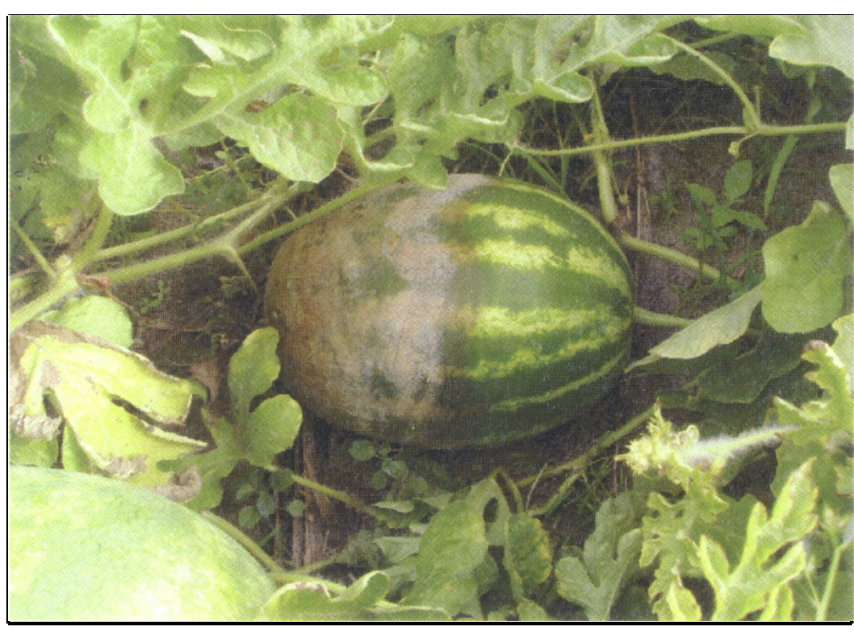

Figure 17. Watermelon fruit with advanced symptoms of Phytophthora blight.

nutrient deficiencies can cause similar symptoms. At this point, microscopic examination is required to discern if characteristic spores of powdery mildew are present. At some point, obvious white, powdery fungal growth may occur. This has been an increasing problem for the past 5 years. Consult with the UF IFAS Cooperative Extension Service for recommended fungicides.

\section{Rind Necrosis}

The characteristic symptom of this disease is the development of light brown, dry corky spots in the rind which may enlarge and merge to form rather extensive necrotic areas that rarely extend into the flesh. There are no external symptoms of rind necrosis, but infected fruits appear to have exceptionally tough rinds in the affected areas. The means of dissemination of the pathogen is not known nor is the etiology of the disease well understood, but apparently infection is limited to the fruits. There are no known controls for this problem, although watermelon varieties differ in the relative incidence and severity of rind necrosis.

\section{Speckle or Moonspots (unknown cause)}

This name refers to the development of small brown, concentric spots on the fruit. The cause or causes are unknown but this condition does not appear to be typical of an infectious disease. It is inheritable. There is no control for this disease.

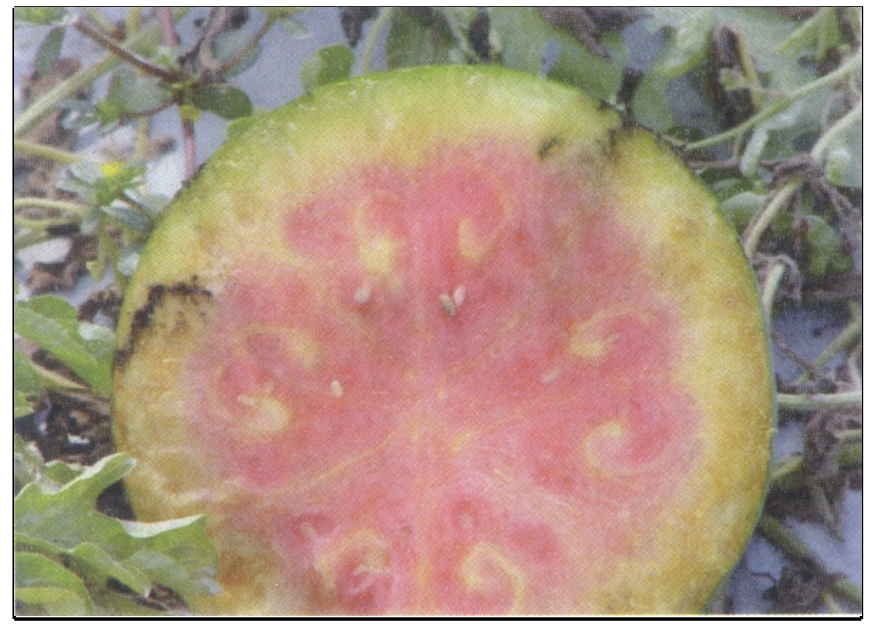

Figure 18. Rind discoloration on watermelon fruit.

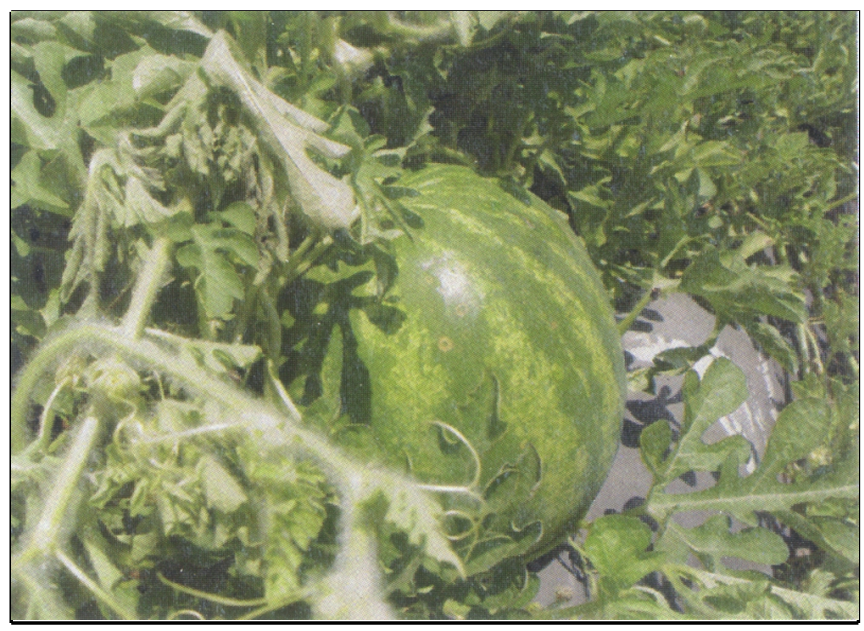

Figure 19. Moonspot symptoms on fruit surface.

\section{Mosaic (Papaya ringspot virus type w, Watermelon mosaic virus 2, Zucchini yellow mosaic virus)}

The most common symptom for these virus diseases is mottling of the leaf (alternate light and dark green areas). However, one or more of the following symptoms may also be associated with mosaic: stunted growth, abnormal leaf shapes, shortened internodes, "bushy" and erect growth habit of the runner tips, and mottled or bumpy appearance of the fruit.

This disease is usually spread by winged aphids during feeding. The aphids pick the virus up from weed hosts such as the creeping cucumber or melonette, Melothria pendula L., in south Florida or alyce clover (Alysicarpus sp.) farther north in the State. Virus transmission requires 9 seconds or less of aphid feeding on watermelon. See Plant Pathology Circular 1184. 
There are few options for management of virus diseases. One method is to remove the inoculum source by removing crop residue after harvest. Another is to eliminate volunteer plants that could serve as sources of virus inoculum during the crop-free periods.

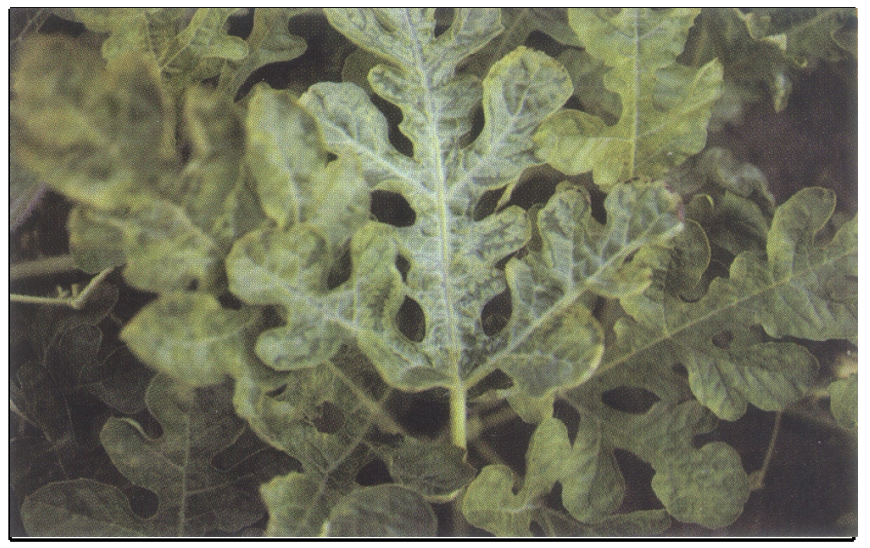

Figure 20. Green vein banding in watermelon leaf (WMV2).

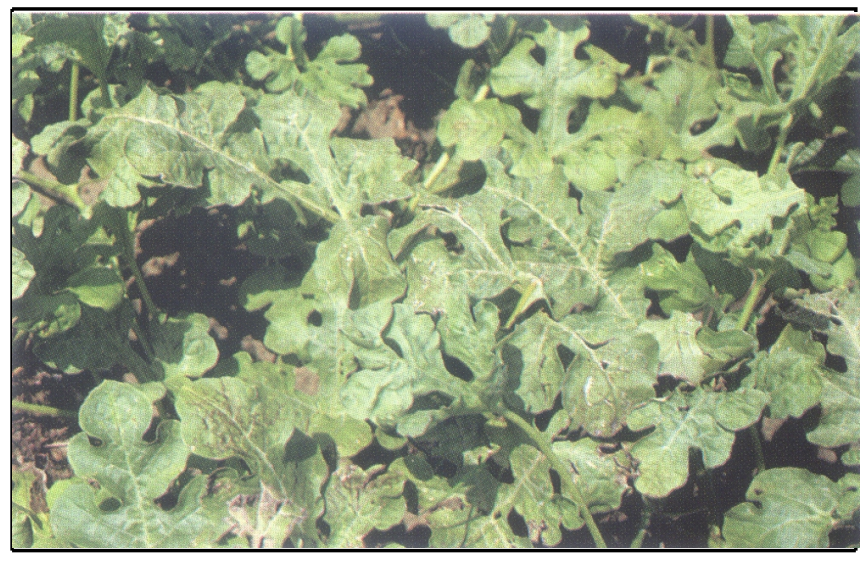

Figure 21. Bronzing and dark and light vein banding in watermelon leaves (WMV2).

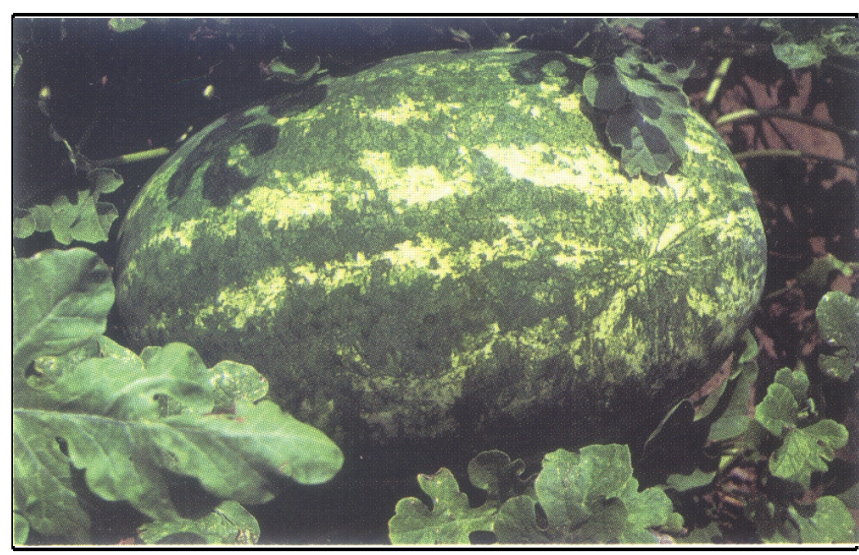

Figure 22. Mosaic in watermelon fruit (WMV2).

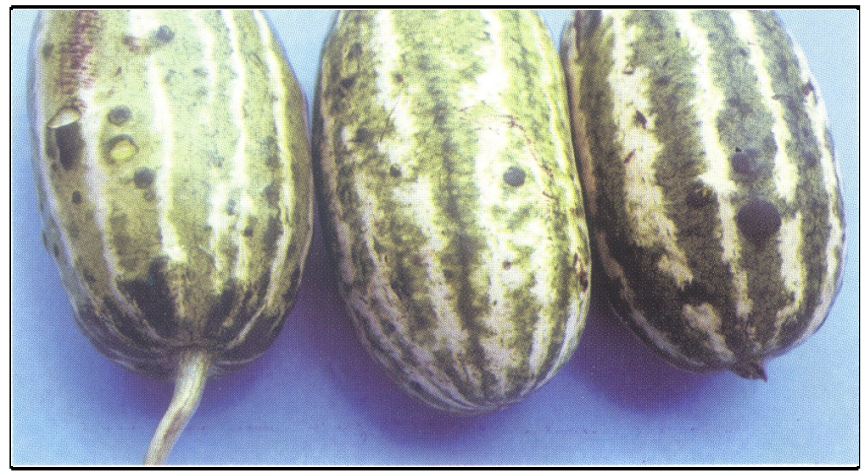

Figure 23. Mosaic and bumps in watermelon fruit (ZYMV + WMV2).

\section{Some tips on disease prevention for watermelon:}

1. Plant to "new ground", if possible. Do not follow cucurbit plantings (i.e., cucumber, cantaloupe, watermelon, and etc) with another cucurbit.

2. Purchase western grown seeds.

3. Purchase treated seeds.

4. Destroy litter from previous crop and bury deeply in the soil.

5. Treat for nematodes.

6. Do not over- or under-water plants and give adequate but not excessive fertilizer.

7. Examine plants frequently for appearance of plant disease symptoms and treat as quickly as possible. 